\title{
ANALISA POTENSI SUMUR-SUMUR TUA MIGAS UNTUK KEGIATAN PRODUKSI ULANG MENGGUNAKAN SISTEM INFORMASI GEOGRAFIS (Studi Kasus : Lapangan Kawengan, Bojonegoro)
}

\author{
Rina Fitryana, Teguh Hariyanto \\ Program Studi Teknik Geomatika FTSP-ITS, Kampus ITS Sukolilo, Surabaya, 60111 \\ Email : rinafitryana@yahoo.com
}

\begin{abstract}
Abstrak
Lapangan Kawengan merupakan lahan tidur yang tidak dimanfaatkan keberadaannya karena dinilai tidak ekonomis. Namun ternyata lapangan merupakan Lapangan yang ternyata termasuk lapangan yang memiliki potensi yang cukup besar untuk dikembangkan (Lemigas,2007). Lapangan Kawengan merupakan lapangan migas tua yang memiliki titik sumur terbanyak. Semakin menipisnya cadangan migas dan langkanya penemuan lapangan migas baru, membuka peluang untuk revitalisasi beberapa lapangan tua.
\end{abstract}

Analisa potensi sumur tua migas di Lapangan Kawengan Bojonegoro ini menggunakan data yang diperoleh dari Dinas ESDM Prov. Jatim berupa peta dijital adiministrasi dan peta tematik dengan skala 1:25000, serta data tabular pendukung lainnya. Untuk menganalisa potensi produksi, diperlukan beberapa parameter, diantaranya aksesibilitas jalan, kondisi tutupan lahan, dan volume sisa cadangan minyak. Setelah dilakukan analisa parameter, lalu melakukan pembagian kelas kesesuaian berdasarkan nilai jarak terdekat.

Hasil yang diperoleh dari analisa potensi migas ini adalah bahwa sumur yang memiliki aksesibilitas jalan yang paling terjangkau yaitu KW-50 yang terletak di kawasan Blok-4 dengan nilai 0,520m dengan kawasan terdiri dari pemukiman dan tanah ladang. Namun, dari segi volume sisa cadangan minyak, blok 4 memiliki volume sisa dengan kriteria sedang, yaitu 14131,25 MSTB dengan produksi rata-rata harian sebesar 99,86 BPOD.

Kata Kunci : Sumur Tua Migas, Lapangan Kawengan, Sistem Informasi Geografis (SIG).

\section{PENDAHULUAN}

\section{Latar Belakang}

Kabupaten Bojonegoro memiliki lapangan sumur tua migas yang cukup potensial, yaitu Lapangan Kawengan, lapangan tua yang sampai saat ini merupakan lapangan yang masih aktif berproduksi. Semakin menipisnya cadangan migas dan langkanya penemuan lapangan migas baru, membuka peluang untuk mengoptimalkan produksi dari beberapa lapangan tua. Salah satu model yang dikembangkan untuk meningkatkan efisiensi serta optimasi produksi adalah merehabilitasi dan menghidupkan kembali sumur-sumur tua migas yang telah ditutup.

Sebagian besar keberadaan minyak dan gas bumi dari sumur-sumur tua yang ditinggalkan masih mengalirkan rembesan minyak yang menyebar di beberapa tempat seperti halnya di Lapangan Kawengan, Kabupaten Bojonegoro, Jawa Timur.
Usaha untuk mengembangkan dan mengaktifkan kembali sumur produksi di lapangan tua merupakan alternatif untuk penemuan cadangan sumberdaya migas baru dengan cara ekstensifikasi melalui produksi, namun kegiatan ini sangat sulit dan mengandung resiko yang cukup tinggi.

Dengan adanya persoalan diatas, maka diperlukan suatu rancangan Sistem Informasi Geografis (SIG) untuk menganalisa sumur-sumur tua migas di Lapangan Kawengan Bojonegoro yang berpotensi untuk produksi ulang. Potensi sumur-sumur tua di Lapangan Kawengan Bojonegoro untuk produksi ulang nantinya ditunjukkan oleh parameter-parameter tertentu.

\section{Perumusan Masalah}

Perumusan yang dimunculkan dalam penelitian ini adalah bagaimana membuat suatu sistem informasi geografis (SIG) untuk menganalisa potensi sumur tua migas di Lapangan Kawengan 
Bojonegoro agar bisa diproduksi ulang berdasarkan parameter tertentu.

\section{Batasan Masalah}

Batasan Masalah dari penelitian ini adalah:

1. Wilayah studi yang digunakan dalam penelitian ini adalah Lapangan Kawengan yang ada di Kabupaten Bojonegoro.

2. Data yang digunakan adalah Peta Batas Administrasi Kab. Bojonegoro, Peta Sebaran Lokasi Sumur Tua Migas Lapangan Kawengan, Peta Jaringan Jalan, Peta Jaringan Transportasi, dan Peta Tutupan Lahan.

3. Data-data mengenai sumur-sumur tua migas, yaitu data tabular yang terdiri dari nama sumur, tahun pemboran, lokasi sumur, Produksi Rata-Rata Harian, dan volume sisa sumur tua migas Lapangan Kawengan, Kab. Bojonegoro.

4. Penentuan parameter-parameter terhadap potensi sumur tua migas untuk produksi ulang.

5. Menganalisa potensi sumur tua migas di Lapangan Kawengan Bojonegoro untuk kegiatan produksi ulang berdasarkan parameter-parameter tertentu.

\section{Tujuan Penelitian}

Tujuan penulisan Tugas Akhir ini adalah membuat suatu SIG untuk menganalisa potensi sumur-sumur tua migas di Lapangan Kawengan Bojonegoro yang bisa diproduksi ulang.

\section{Manfaat Penelitian}

Manfaat yang dapat diperoleh dari penelitian ini adalah dapat memberikan informasi mengenai sumur-sumur tua migas mana saja yang masih berpotensi untuk diproduksi ulang dilihat berdasarkan parameter-parameter yang digunakan dengan metode SIG sehingga dapat dijadikan sebagai bahan masukan dan pertimbangan bagi pihak pengembang, investor, atau perusahaan yang bergerak di bidang minyak dan gas, khususnya bagi Dinas Energi dan Sumber Daya Mineral (ESDM) Jawa Timur.

\section{METODOLOGI PENELITIAN}

\section{Lokasi Penelitian}

Lokasi dalam penelitian ini mengambil daerah studi di Lapangan Kawengan, Bojonegoro. Secara geografis,lokasi ini berjarak kurang lebih $22 \mathrm{~km}$ sebelah Timur laut Cepu, $176 \mathrm{~km}$ sebelah Timur Semarang, $145 \mathrm{~km}$ sebelah Barat Surabaya dan secara astronomis berada pada $07^{\circ} 05^{\prime}$ LS dan $111^{\circ} 42^{\prime}$ BT (Lemigas,2007). Berikut ini adalah lokasi penelitian:

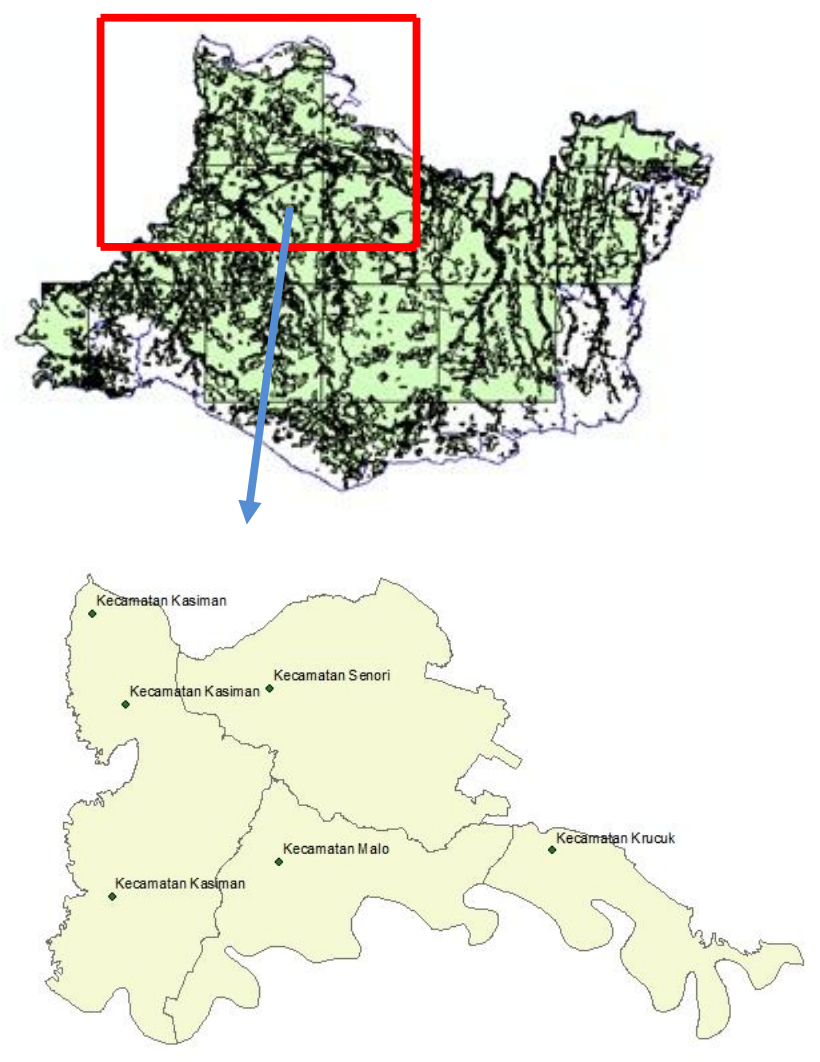

Gambar 1. Lokasi Penelitian

\section{Data dan Peralatan}

\section{Data}

Data yang digunakan dalam penelitian ini adalah:

1. Peta Digital Batas Administrasi dan Peta Jaringan Jalan Kabupaten Bojonegoro skala 1:25.000 (UTM).

2. Peta Tematik Tutupan Lahan Kabupaten Bojonegoro skala 1:25.000 (UTM)

3. Laporan akhir Dinas Energi dan Sumber Daya Mineral Prov. Jawa Timur tahun 2007 mengenai inisiasi pengembangan sumur tua migas. 
4. Data-data mengenai sumur-sumur tua migas, yaitu data tabular yang terdiri dari nama sumur, tahun pemboran,koordinat sumur, Volum Sisa Cadangan Minyak, Produksi Rata-Rata Harian, dan Data Sosial Ekonomi Lapangan Kawengan, Kab. Bojonegoro.

\section{- Peralatan}

Peralatan yang digunakan dalam penelitian ini adalah:

1. Perangkat Keras (Hardware)
a. Personal Computer (PC) / Notebook
b. Printer

2. Perangkat Lunak (Software)
a. Microsoft Office2007
b. ArcGIS 9.3
c. AutoCad Landesktop 2006
d. Visual Basic 6.0

\section{Diagram Alir Pengolahan Data}

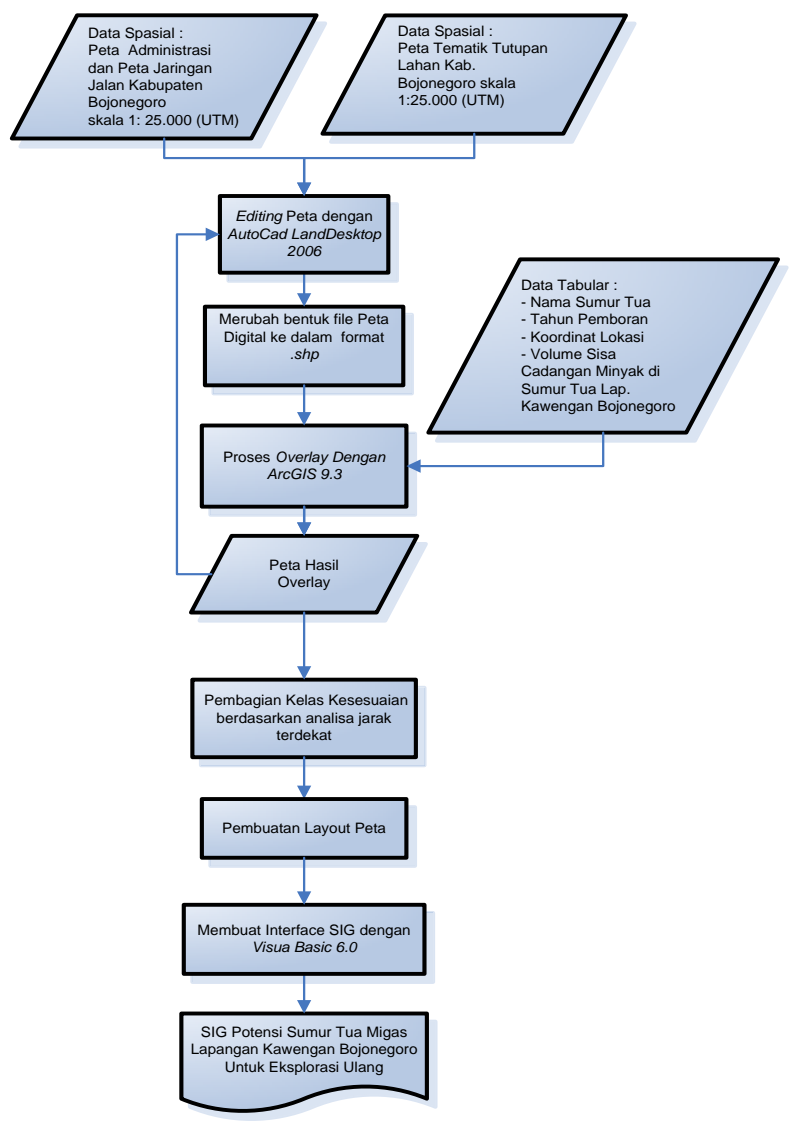

\section{Gambar 2. Diagram Tahap Pengolahan Data}

Berikut adalah penjelasan diagram alir tahapan pengolahan data :

1. Data
Peta Digital Batas Administrasi,Peta Jaringan Jalan, dan Peta Tematik Tutupan Lahan Kabupaten Bojonegoro skala 1:25.0000 (UTM). Data tersebut diperoleh dari Dinas ESDM Prov. Jatim. Serta data tabular yang terdiri dari nama sumur, tahun pemboran, lokasi sumur, dan data Volume Sisa Cadangan Minyak Lapangan Kawengan, Kab. Bojonegoro.

2. Editing Peta dengan AutoCad LandDesktop 2006

Melakukan proses Editing 2 peta digital Kabupaten Bojonegoro skala 1:25000 dengan menggunakan software autoCad LandDesktop 2006

3. Merubah Bentuk file peta digital ke dalam foormat .shp

Melakukan eksport peta yang telah diedit kedalam bentuk file shp menggunakan AutoCad LandDesktop 2006 dengan cara klik map $\rightarrow$ tools $\rightarrow$ export, lalu simpan jenis file dengan format .shp.

4. Proses Overlay dengan ArcGIS 9.3

Melakukan overlay layer-layer peta yang sudah berformat shp berdasarkan parameter-parameter yang digunakan, yaitu aksesibilitas (keterjangkauan) jalan, kondisi tutupan lahan yang ada di sekitar lokasi sumur tua migas, dan volum sisa cadangan minyak yang masih bisa untuk diproduksi ulang menggunakan software ArcG/S 9.3. selanjutnya melakukan analisa spasial untuk mendapatkan hasil yang akan digunakan dalam analisa pembagian kelas, yaitu melakukan analisa mengenai radius maksimal keterjangkauan jalan dengan proses buffering, dan analisa besar jarak terdekat yang bisa ditempuh antara jalan dan lokasi sumur tua.

Besarnya nilai radius maksimal aksesibilitas jalan dihitung dengan menggunakan rumus :

$A=L / P$

Dengan : $\mathrm{A}=$ aksesibilitas

$L=$ jumlah luas wilayah yang diteliti $\left(\mathrm{m}^{2}\right)$

$\mathrm{P}=$ jumlah panjang jalan $(\mathrm{m})$

Berikutnya yaitu melakukan proses pemasukan atribut data tabular yang terdiri dari nama sumur tua, tahun pengeboran, koordinat lokasi $(x, y)$, dan data volume sisa cadangan minyak sumur tua yang masih bisa diproduksi. 
Dari proses overlay ini akan menghasilkan peta hasil overlay, yaitu Peta Jangkauan Jalan dan Peta Tutupan Lahan Lapangan Kawengan Bojonegoro skala 1:150.000 (UTM). Apabila tidak didapatkan hasil, maka perlu dilakukan peninjauan kembali terhadap data yang digunakan dan dilakukan editing ulang pada AutoCad 2006.

5. Pembagian kelas kesesuaian berdasarkan analisa jarak terdekat

Melakukan analisa potensi sumur migas berdasarkan hasil analisa jarak terdekat antara lokasi sumur tua migas dengan jalan dan tutupan lahan yang ada di sekitarnya.

6. Pembuatan Layout Peta

Melakukan pembuatan layout dengan ArcGIS 9.3.

7. Membuat interface SIG dengan VisualBasic 6.0

Membuat tampilan SIG sehingga bisa dinikmati dan digunakan oleh user dengan menggunakan software VisualBasic 6.0

8. Hasil dari penelitian ini adalah SIG Analisa Potensi Sumur Tua Migas Lapangan Kawengan Bojonegoro Untuk Produksi Ulang.

\section{HASIL DAN PEMBAHASAN}

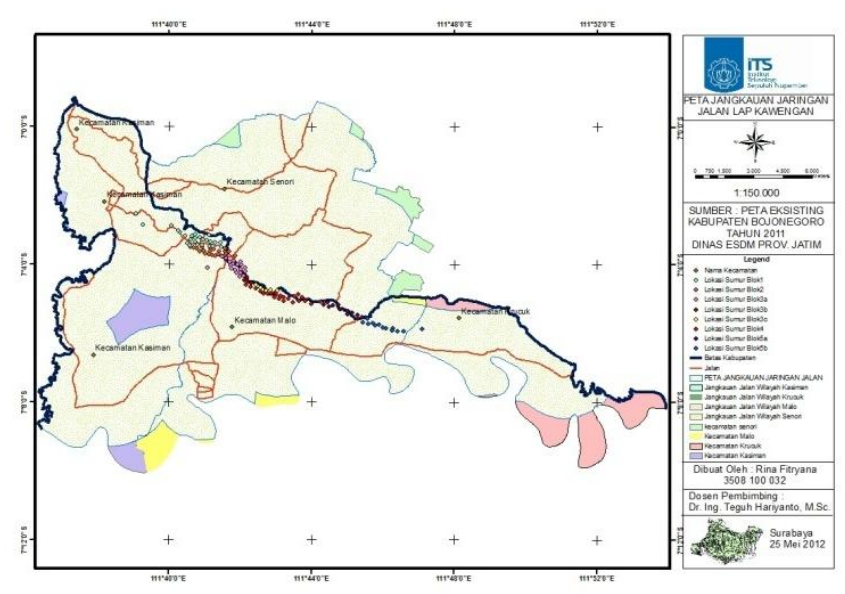

Gambar 4. Peta Jangkauan Jalan Lap. Kawengan Bojonegoro
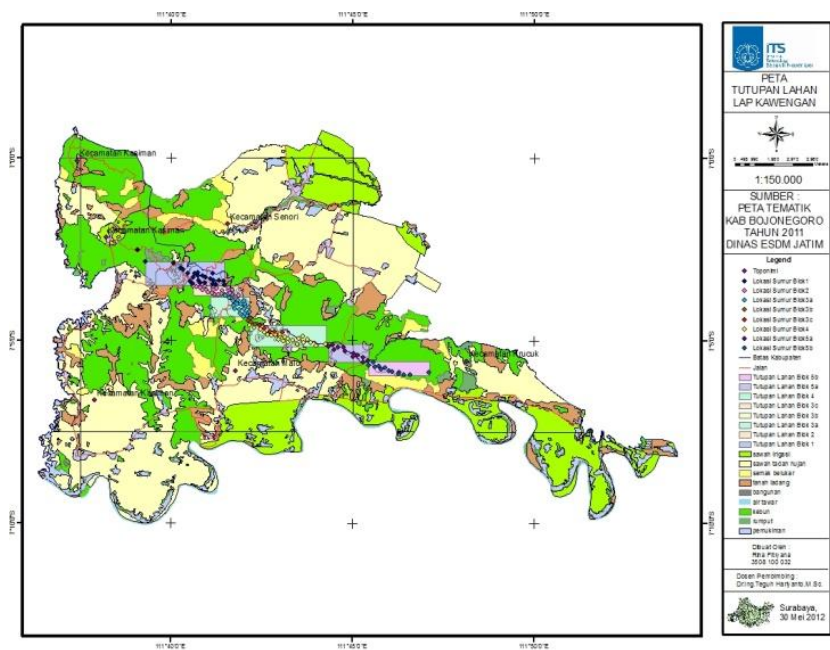

Gambar 5. Peta Tutupan Lahan Lap. Kawengan 
Tabel 1. Analisa Sumur Tua Migas Blok 4

Berdasarkan Tiap Parameter

\begin{tabular}{|c|c|c|c|c|}
\hline \multicolumn{5}{|c|}{ Analisa Potensi Sumur Tua Migas Lapangan Kawengan } \\
\hline Nama Blok & $\begin{array}{c}\text { Volume Sisa Cadangan } \\
\text { (MSTB) }\end{array}$ & Jenis Tutupan Lahan & Aksesibilitas Jalan (m) & Nama Sumur \\
\hline \multirow{24}{*}{ Blok 4} & \multirow{24}{*}{14131,25} & Kebun & 187,834 & KW-E-85 \\
\hline & & Sawah Tadah Hujan & 18,294 & KW-66 \\
\hline & & Tanah Ladang & 258,660 & KW-99 \\
\hline & & Pemukiman & 74,424 & KW-37 \\
\hline & & & 112,565 & KW-36 \\
\hline & & & 174,867 & KW-123 \\
\hline & & & 0,519 & KW-50 \\
\hline & & & 29,697 & KW-50A \\
\hline & & & 286,068 & KW-126 \\
\hline & & & 373,754 & KW-116 \\
\hline & & & 280,768 & KW-64 \\
\hline & & & 250,344 & KW-24 \\
\hline & & & 180,042 & KW-94 \\
\hline & & & 263,475 & KW-68 \\
\hline & & & 437,881 & KW-109 \\
\hline & & & 203,682 & KW-35 \\
\hline & & & 8,156 & KW-15 \\
\hline & & & 43,720 & KW-27 \\
\hline & & & 268,521 & KW-23 \\
\hline & & & 99,501 & KW-117 \\
\hline & & & 207,314 & KW-107 \\
\hline & & & 82,349 & KW-34 \\
\hline & & & 132,539 & KW-31 \\
\hline & & & 12,792 & KW-113 \\
\hline
\end{tabular}

Berdasarkan tabel diatas dapat disimpulkan bahwa :

Blok 4 memiliki volume sisa cadangan minyak yang paling besar yaitu 14131,25 MSTB.

Tabel 2. Analisa Sumur Tua Migas Blok 2 Berdasarkan Tiap Parameter

Analisa Potensi Sumur Tua Migas Lapangan Kawengan

\begin{tabular}{ccccc}
\hline \multicolumn{2}{c}{ Analisa Potensi Sumur Tua Migas Lapangan Kawengan } & & \\
Nama Blok & Volume Sisa Cadangan (MSTB) & Jenis Tutupan Lahan & Aksesibilitas Jalan (m) & Nama Sumur \\
\hline & & Kebun & 190,850 & KW-5 \\
Blok 2 & Rumput & 187,565 & KW-6 \\
& \multirow{2}{*}{10379,5} & Pemukiman & 290,013 & KW-8 \\
& & 324,722 & KW-1 \\
& & 388,230 & KW-42 \\
\hline
\end{tabular}

Blok ini memiliki tutupan lahan yang tediri dari Kebun (dengan luas terbesar), Sawah Tadah

Dari kondisi jaringan jalan, blok ini memiliki ratarata jarak terdekat sebesar $166,1569 \mathrm{~m}$. Untuk sumur yang terdekat dengan jalan yaitu KW-50 dengan jarak 0,52 m. Hujan, Tanah Ladang, dan Pemukiman. 


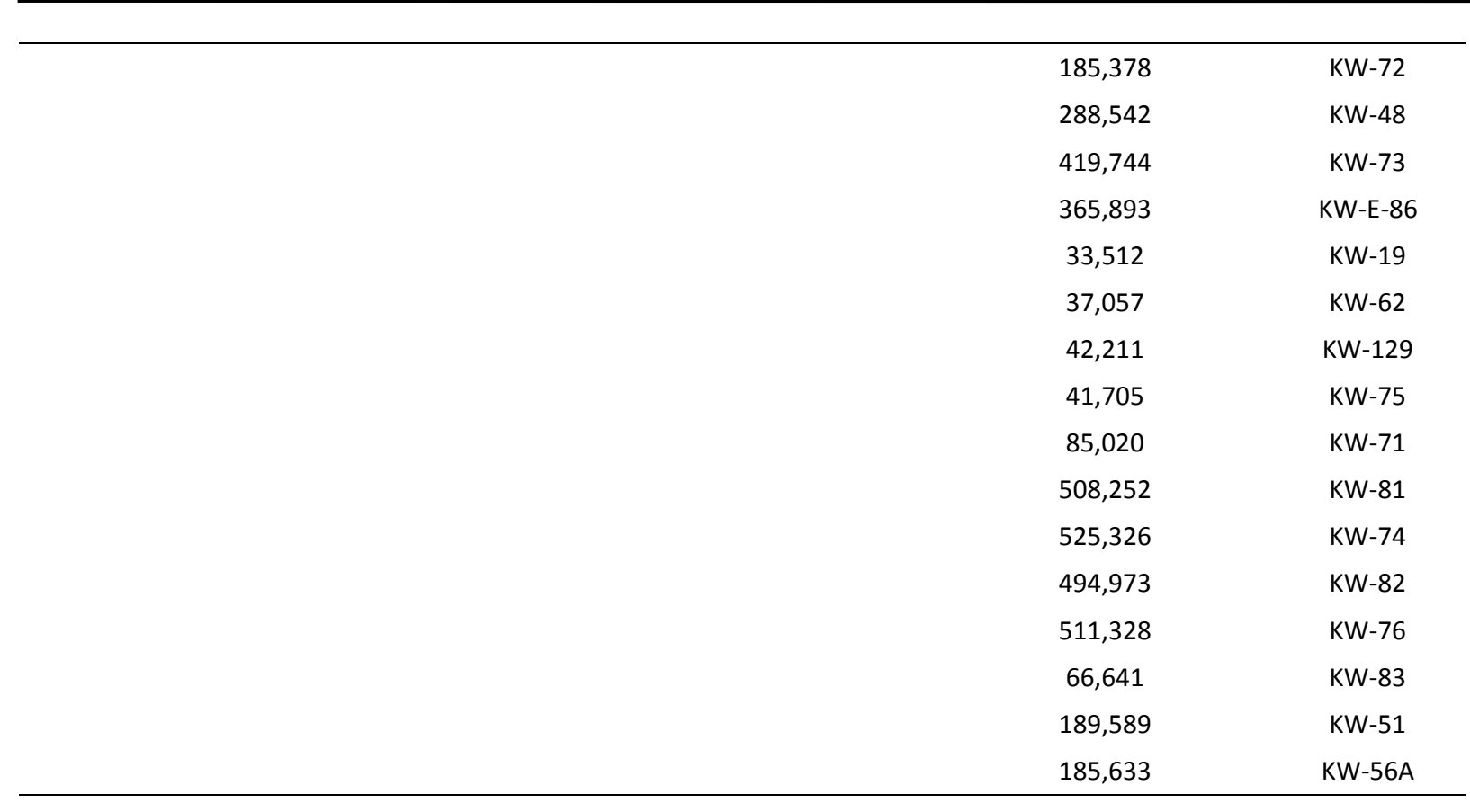

Berdasarkan tabel diatas dapat disimpulkan bahwa:

Blok 2 memiliki volume sisa cadangan minyak kedua terbesar 10379,5 MSTB.

Tabel 3. Analisa Sumur Tua Migas Blok 1

Berdasarkan Tiap Parameter

\begin{tabular}{|c|c|c|c|c|}
\hline \multicolumn{5}{|c|}{ Analisa Potensi Sumur Tua Migas Lapangan Kawengan } \\
\hline $\begin{array}{l}\text { Nama } \\
\text { Blok }\end{array}$ & $\begin{array}{c}\text { Volume Sisa Cadangan } \\
\text { (MSTB) }\end{array}$ & Jenis Tutupan Lahan & Aksesibilitas Jalan (m) & Nama Sumur \\
\hline & & Kebun & 68,362 & $\mathrm{KW}-2$ \\
\hline & & Sawah Tadah Hujan & 17,864 & KW-3 \\
\hline & & Pemukiman & 38,099 & KW-9 \\
\hline & & Tanah Ladang & 20,722 & KW-100 \\
\hline & & Air Tawar & 75,652 & KW-E-89 \\
\hline & & & 137,238 & KW-92 \\
\hline & & & 172,516 & KW-70 \\
\hline & & & 155,557 & KW-97 \\
\hline & & & 85,526 & KW-124 \\
\hline \multirow[t]{10}{*}{ Blok 1} & 2839,91 & & 169,792 & KW-127 \\
\hline & & & 79,265 & KW-65 \\
\hline & & & 84,891 & KW-21 \\
\hline & & & 113,313 & KW-11 \\
\hline & & & 298,975 & KW-118 \\
\hline & & & 309,652 & KW-125 \\
\hline & & & 376,334 & KW-128 \\
\hline & & & 129,313 & KW-56 \\
\hline & & & 109,391 & KW-E-88 \\
\hline & & & 155,168 & KW-25 \\
\hline
\end{tabular}

Blok ini memiliki tutupan lahan antara lain Kebun, rumput, dan Pemukiman. Dari kondisi jaringan jalan, blok ini memiliki rata-rata jarak terdekat sebesar $255,3421 \mathrm{~m}$. Untuk sumur yang terdekat dengan jalan yaitu KW-19 dengan jarak $33,512 \mathrm{~m}$. 


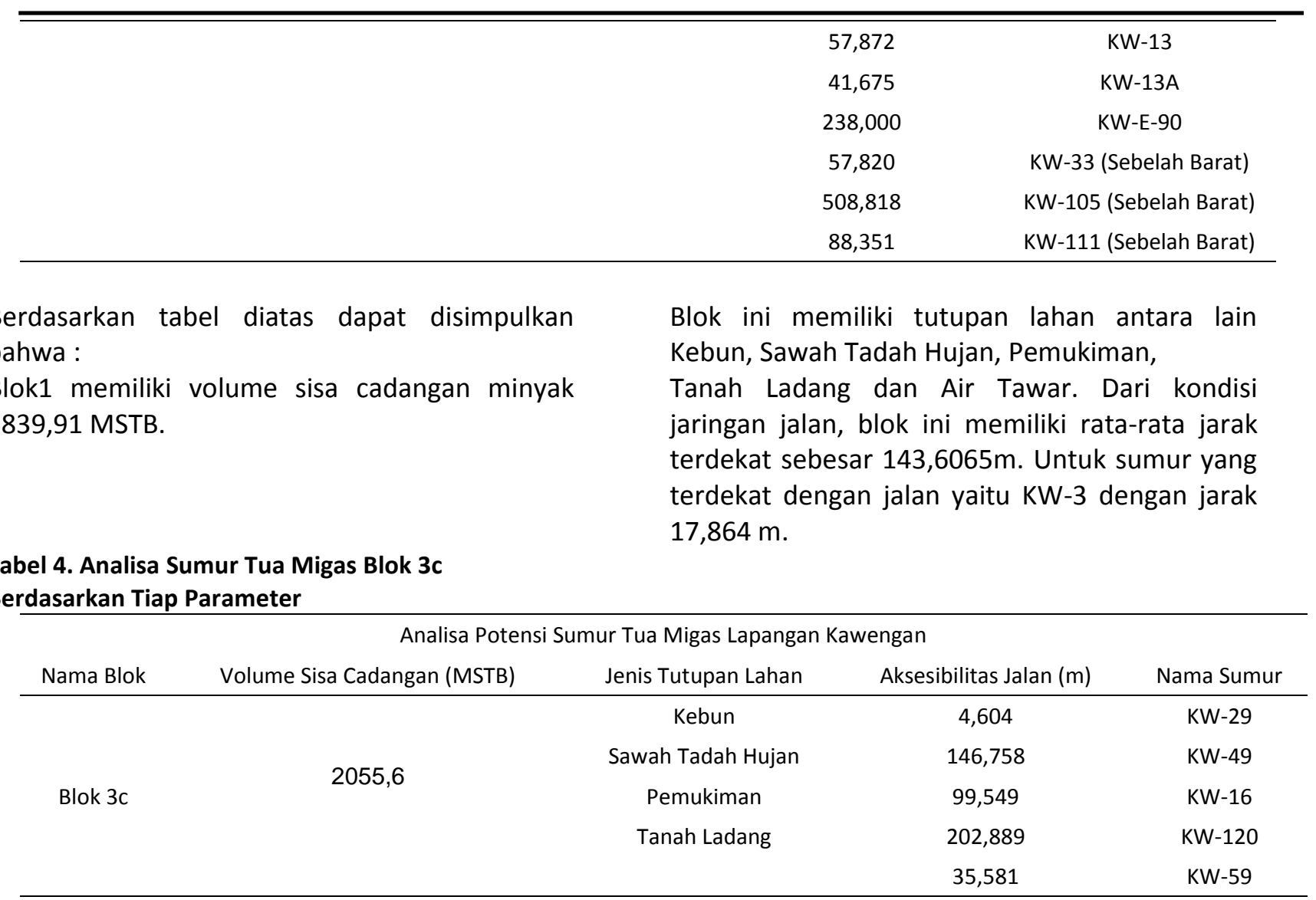

Berdasarkan tabel diatas dapat disimpulkan bahwa :

Blok3c memiliki volume sisa cadangan minyak 2055,6 MSTB.

Tabel 5. Analisa Sumur Tua Migas Blok 5a Berdasarkan Tiap Parameter

Analisa Potensi Sumur Tua Migas Lapangan Kawengan

\begin{tabular}{|c|c|c|c|c|}
\hline \multicolumn{5}{|c|}{ Analisa Potensi Sumur Tua Migas Lapangan Kawengan } \\
\hline Nama Blok & Volume Sisa Cadangan (MSTB) & Jenis Tutupan Lahan & Aksesibilitas Jalan (m) & Nama Sumur \\
\hline \multirow{12}{*}{ Blok 5a } & \multirow{12}{*}{1593,4} & Kebun & 113,058 & KW-30 \\
\hline & & Sawah Tadah Hujan & 30,090 & KW-E-84 \\
\hline & & Tanah Ladang & 225,714 & KW-77 \\
\hline & & Belukar & 46,794 & KW-121 \\
\hline & & Rumput & 31,034 & KW-119 \\
\hline & & & 119,287 & KW-102 \\
\hline & & & 116,608 & KW-106 \\
\hline & & & 156,452 & KW-32 \\
\hline & & & 238,646 & KW-115 \\
\hline & & & 401,685 & KW-112 \\
\hline & & & 349,074 & KW-41 \\
\hline & & & 184,020 & KW-45 \\
\hline
\end{tabular}

Blok ini memiliki tutupan lahan antara lain Kebun, Sawah Tadah Hujan, Pemukiman, dan Tanah Ladang . Dari kondisi jaringan jalan, blok ini memiliki rata-rata jarak terdekat sebesar $97,876 \mathrm{~m}$. Untuk sumur yang terdekat dengan jalan yaitu KW-29 dengan jarak 4,604 m. 
Berdasarkan tabel diatas dapat disimpulkan bahwa :

Blok5a memiliki volume sisa cadangan minyak 1593,4 MSTB.

Tabel 6. Analisa Sumur Tua Migas Blok 3a Berdasarkan Tiap Parameter
Blok ini memiliki tutupan lahan antara lain Kebun, Sawah Tadah Hujan, Tanah Ladang, Belukar, Rumput. Dari kondisi jaringan jalan, blok ini memiliki rata-rata jarak terdekat sebesar $157,7052 \mathrm{~m}$. Untuk sumur yang terdekat dengan jalan yaitu KW E-84dengan jarak 30,090 m.

\begin{tabular}{|c|c|c|c|c|}
\hline \multicolumn{5}{|c|}{ Analisa Potensi Sumur Tua Migas Lapangan Kawengan } \\
\hline Nama Blok & Volume Sisa Cadangan (MSTB) & Jenis Tutupan Lahan & Aksesibilitas Jalan (m) & Nama Sumur \\
\hline & & Kebun & 11,020 & KW-20 \\
\hline & & Tanah Ladang & 235,133 & KW-69 \\
\hline & & Belukar & 195,158 & KW-93 \\
\hline & & Pemukiman & 12,993 & KW-E-87 \\
\hline & & Rumput & 2,364 & KW-10 \\
\hline & & Bangunan & 165,605 & KW-57 \\
\hline & & & 74,999 & KW-54 \\
\hline & & & 35,753 & KW-12 \\
\hline & & & 236,498 & KW-104 \\
\hline & & & 207,116 & KW-53 \\
\hline \multirow[t]{11}{*}{ Blok 3a } & 1524,31 & & 56,288 & KW-17 \\
\hline & & & 65,298 & KW-79 \\
\hline & & & 84,296 & KW-14 \\
\hline & & & 176,401 & KW-110 \\
\hline & & & 225,278 & KW-52 \\
\hline & & & 273,274 & KW-95 \\
\hline & & & 139,559 & KW-E-91 \\
\hline & & & 244,161 & KW-60 \\
\hline & & & 284,076 & KW-26 \\
\hline & & & 265,828 & KW-108 \\
\hline & & & 556,227 & KW-4 \\
\hline
\end{tabular}

Berdasarkan tabel diatas dapat disimpulkan bahwa :

Blok3a memiliki volume sisa cadangan minyak 1524,31MSTB.

Tabel 7. Analisa Sumur Tua Migas Blok 5b Berdasarkan Tiap Parameter

Analisa Potensi Sumur Tua Migas Lapangan Kawengan

\begin{tabular}{ccccc}
\hline \multicolumn{4}{c}{ Analisa Potensi Sumur Tua Migas Lapangan Kawengan } & \\
Nama Blok & Volume Sisa Cadangan (MSTB) & Jenis Tutupan Lahan & Aksesibilitas Jalan (m) & Nama Sumur \\
\hline \multirow{3}{*}{ Blok 5b } & & Belukar & 404,990 & $\mathrm{KW}-28$ \\
& \multirow{2}{*}{935,45} & Kebun & 692,879 & $\mathrm{KW}-40$ \\
& & & 897,377 & $\mathrm{KW}-78$ \\
& & 641,348 & $\mathrm{KW}-103$ \\
\hline
\end{tabular}

Blok ini memiliki tutupan lahan antara lain Kebun, Tanah Ladang, Belukar, Pemukiman,Rumput, Bangunan.

Dari kondisi jaringan jalan, blok ini memiliki ratarata jarak terdekat sebesar 168,9201 m. Untuk sumur yang terdekat dengan jalan yaitu KW-10 dengan jarak 2,364 $\mathrm{m}$. 


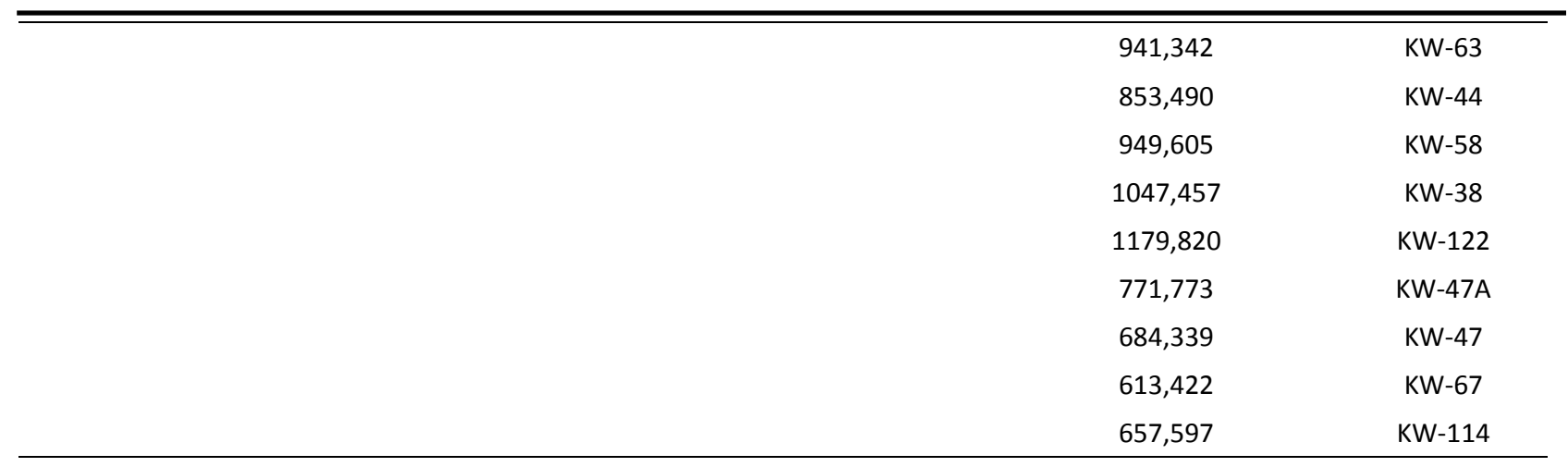

Berdasarkan tabel diatas dapat disimpulkan bahwa :

Blok3a memiliki volume sisa cadangan minyak 935,45 MSTB.

Tabel 8. Analisa Sumur Tua Migas Blok 3b Berdasarkan Tiap Parameter

Analisa Potensi Sumur Tua Migas Lapangan Kawengan

\begin{tabular}{|c|c|c|c|c|}
\hline Nama Blok & Volume Sisa Cadangan (MSTB) & Jenis Tutupan Lahan & Aksesibilitas Jalan (m) & Nama Sumur \\
\hline \multirow{4}{*}{ Blok 3b } & \multirow{4}{*}{429,06} & Kebun & 2,511 & KW-98 \\
\hline & & Tanah Ladang & 65,711 & KW-80 \\
\hline & & & 142,815 & KW-61 \\
\hline & & & 0,669 & KW-18 \\
\hline
\end{tabular}

Berdasarkan tabel diatas dapat disimpulkan bahwa :

Blok3b memiliki volume sisa cadangan minyak 429,06 MSTB.

Blok ini memiliki tutupan lahan antara lain Kebun dan Tanah Ladang.

Dari kondisi jaringan jalan, blok ini memiliki ratarata jarak terdekat sebesar 52,93 m. Untuk sumur yang terdekat dengan jalan yaitu KW-18 dengan jarak 0,669 m.

\section{KESIMPULAN DAN SARAN}

\section{Kesimpulan}

Dari penelitian yang telah dilakukan, dapat disimpulkan sebagai berikut :

1. Telah dibuat suatu Sistem Informasi Geografis yang berbasis sebaran sumur tua migas beserta potensi yang ada.

2. Didapatkan potensi volume sisa cadangan migas yang terbesar adalah blok 4 dengan nilai 14131,25 MSTB. Sedangkan sumur yang memiliki potensi volume migas terkecil adalah blok 3b yaitu 429,06 MSTB.
Blok ini memiliki tutupan lahan antara lain Belukar, Kebun.

Dari kondisi jaringan jalan, blok ini memiliki ratarata jarak terdekat sebesar 795,034 m. Untuk sumur yang terdekat dengan jalan yaitu KW-28 dengan jarak 404,990 m.
3. Masing-masing blok memiliki akses jalan dan sebaran tutupan lahan yang berbeda. Berdasarkan kedua kriteria tersebut, maka didapatkan hasil bahwa sumur tua yang berpotensi untuk diproduksi ulang adalah sumur yang terletak di kawasan blok 4 dengan kondisi tutupan lahan yang terdiri dari kebun,sawah tadah hujan, tanah ladang, dan pemukiman. Namun masih perlu dilakukan pembebasan lahan untuk tutupan lahan pemukiman.

Saran

Data mengenai migas merupaan data yang tidak dipublikasikan. Untuk itu hendaknya sebelum melakukan penelitian, sebaiknya dilakukan pengumpulan data dan studi literatur sebanyakbanyaknya.

\section{DAFTAR PUSTAKA}

Anonim. 2009. Pengertian Basis Data. <URL http://www.achmad.argha.co.id> Dikunjungi pada tanggal 25 Oktober 2010, jam 14.30 WIB 
Anonim.

2010.

ArcGIS.

<URLhttp://translate.google.co.id/translat e?hl=id\&langpair=en |id

\&u=http://en.wikipedia.org/wiki/ArcGIS>

Dikunjungi pada tanggal 25 November 2011 jam 15.00 WIB

Anonim. 2010. Sistem Informasi Geografis. <URL http://www._library@ittelkom.ac.id> Dikunjungi pada tanggal 25 Oktober 2011,jam 14.30 WIB

Aronoff,S.1989. Geographic Information System : A Management Perspective, Canada: WDL Publications.

Lemigas, 1981. Geologi Daerah Wilayah Kerja Lemigas. Cepu : Laporan PUSDIKLAT Produksi PPTMGB “Lemigas” (tidak dipublikasikan).

Lemigas, 2001. Karakterisasi Geologi Batuan Reservoir Dan Problem Shale Di Jawa - Timur. Jakarta : Riset Lemigas - Pertamina ( tidak dipublikasikan).
Lemigas, 2007. Inisiasi Pengembangan Sumur Tua Migas Lapangan Marginal Kabupaten Bojonegoro, Ngawi, Madiun, Jombang, dan Mojokerto. Jakarta : Riset Lemigas Pertamina ( tidak dipublikasikan).

Mudjiono et al., 2001. Exploration of the North Madura Platform, Offshore East Java. Indonesia: Prosiding Indon. Petrol. Assoc. 28th Ann. Conv., pp 707-726.

Mujito, Suprijanto., 1984. Lingkungan Pengendapan Pasir Ngrayong Formasi Tuban, di Zona Rembang. Jakarta : Proceed. Diskusi Ilmiah V Beberapa Hasil Karya PPPTMGB"LEMIGAS".

Nento, Mursyid. 2005. Laporan Thesis : Analisis dan Perancangan Aplikasi GIS dalam Penentuan Lokasi Pengeboran Sumur Studi Kasus : Lap Minas, Cepu. Surabaya : Program Studi Magister Managemen Teknologi Bidang Keahlian dan Manajemen Teknologi Informasi Program Pascasarjana ITS.. 